\title{
Megacity impacts on regional ozone formation: observations and WRF-Chem modeling for the MIRAGE-Shanghai field campaign
}

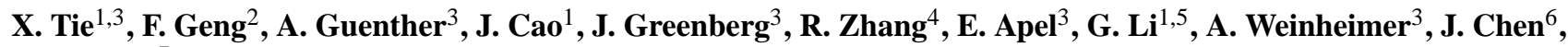 \\ and C. $\mathrm{Cai}^{7}$ \\ ${ }^{1}$ Key Laboratory of Aerosol, SKLLQG, Institute of Earth Environment, Chinese Academy of Sciences, Xian, China \\ ${ }^{2}$ Shanghai Meteorological Bureau, Shanghai, China \\ ${ }^{3}$ National Center for Atmospheric Research, Boulder, CO, USA \\ ${ }^{4}$ Department of Atmospheric Sciences, Texas A\&M, TX, USA \\ ${ }^{5}$ Molina Center for Energy and the Environment, La Jolla, CA, USA \\ ${ }^{6}$ Fudan University, Shanghai, China \\ ${ }^{7}$ North Carolina State University, Raleigh, NC, USA
}

Correspondence to: X. Tie (xxtie@ucar.edu), A. Guenther (guenther@ucar.edu)

Received: 7 December 2012 - Published in Atmos. Chem. Phys. Discuss.: 15 January 2013

Revised: 8 May 2013 - Accepted: 12 May 2013 - Published: 10 June 2013

\begin{abstract}
The MIRAGE-Shanghai experiment was designed to characterize the factors controlling regional air pollution near a Chinese megacity (Shanghai) and was conducted during September 2009. This paper provides information on the measurements conducted for this study. In order to have some deep analysis of the measurements, a regional chemical/dynamical model (version 3 of Weather Research and Forecasting Chemical model - WRF-Chemv3) is applied for this study. The model results are intensively compared with the measurements to evaluate the model capability for calculating air pollutants in the Shanghai region, especially the chemical species related to ozone formation. The results show that the model is able to calculate the general distributions (the level and the variability) of air pollutants in the Shanghai region, and the differences between the model calculation and the measurement are mostly smaller than $30 \%$, except the calculations of HONO (nitrous acid) at PD (Pudong) and CO (carbon monoxide) at DT (Dongtan).

The main scientific focus is the study of ozone chemical formation not only in the urban area, but also on a regional scale of the surrounding area of Shanghai. The results show that during the experiment period, the ozone photochemical formation was strongly under the VOC (volatile organic compound)-limited condition in the urban area of Shanghai. Moreover, the VOC-limited condition occurred not only in the city, but also in the larger regional area. There was a con-
\end{abstract}

tinuous enhancement of ozone concentrations in the downwind of the megacity of Shanghai, resulting in a significant enhancement of ozone concentrations in a very large regional area in the surrounding region of Shanghai. The sensitivity study of the model suggests that there is a threshold value for switching from VOC-limited condition to $\mathrm{NO}_{\mathrm{x}}$ (nitric oxide and nitrogen dioxide)-limited condition. The threshold value is strongly dependent on the emission ratio of $\mathrm{NO}_{\mathrm{x}} /$ VOCs. When the ratio is about 0.4 , the Shanghai region is under a strong VOC-limited condition over the regional scale. In contrast, when the ratio is reduced to about 0.1 , the Shanghai region is under a strong $\mathrm{NO}_{\mathrm{x}}$-limited condition. The estimated threshold value (on the regional scale) for switching from VOC-limited to $\mathrm{NO}_{\mathrm{x}}$-limited condition ranges from 0.1 to 0.2 . This result has important implications for ozone production in this region and will facilitate the development of effective $\mathrm{O}_{3}$ control strategies in the Shanghai region.

\section{Introduction}

Shanghai is the largest city in China. During the past two decades, Shanghai has undergone a rapid increase in economic development. For example, between 1996 and 2008 the industrial gross output increased from 0.51 to 2.56 trillion RMB (about 0.37 trillion USD), and the number of 
automobiles increased from 0.47 to 2.61 million (SMSB, 2008). Accompanying the rapid economic development, the air quality has deteriorated in recent years, leading to a significant increase in the concentrations of air pollutants such as $\mathrm{NO}_{\mathrm{x}}$ and $\mathrm{O}_{3}$ in Shanghai (Geng et al., 2007, 2008). Thus, a better understanding of the characteristics of precursors of $\mathrm{O}_{3}$ becomes an important issue for studying ozone formation and for developing effective $\mathrm{O}_{3}$ control strategies in Shanghai.

Several studies regarding the air pollution in the Shanghai region have been described (Jiang et al., 2004; Zhao et al., 2004; Yang et al., 2005; Geng et al., 2007, 2011; Tang et al., 2008; Tie et al., 2009a; Cai et al., 2010). Jiang et al. (2004) studied the air pollution index (API) for $\mathrm{PM}_{10}, \mathrm{SO}_{2}$, and $\mathrm{NO}_{2}$. Zhao et al. (2004) studied the results obtained from the CHINA-MAP project, and suggested that small-scale dynamical processes have important influences on the distribution of $\mathrm{O}_{3}$ concentrations in this region. Yang et al. (2005) measured black and organic carbons in Shanghai. They found that the concentrations of organic carbons were normally about two times higher than the concentrations of black carbon. Geng et al. (2007) suggested that $\mathrm{O}_{3}$ chemical production is limited by the concentrations of volatile organic compounds (VOCs) in the city of Shanghai. Among the different VOC species, aromatics and alkenes play important roles for the formation of ozone. Tang et al. (2008) studied the "weekend" effect. Their study suggested that the reduction of $\mathrm{NO}_{\mathrm{x}}$ during weekend produces an increase in ozone concentrations. Tie et al. (2009a) used a regional chemical/transport model (WRF-Chem) to study the variability of air pollutants in the Shanghai region, and found that meteorological conditions play important roles in controlling the variability of air pollutants in the Shanghai region. Cai et al. (2010) used a receptor model (PCA/APCS; Principal Component Analysis/Absolute Principal Component Scores) to identify the individual contributions of different VOC sources to VOC concentrations. Their result suggested that liquefied petroleum, gasoline, and solvent usages had important contributions to the VOC concentrations in the Shanghai region. Geng et al. (2011) studied the effect of major forests in the south of Shanghai on ozone formation. Their result suggested that there is a large amount of isoprene that is emitted from forests. As a result, the carbonyls that are formed from the process of oxidation of isoprene can be transported to the Shanghai region, and the further oxidation of the carbonyls leads to the chemical formation of ozone in Shanghai, enhancing the ozone concentration by about $20 \%$. These previous studies provide very useful information regarding the air pollution situations, especially ozone chemical formation in the Shanghai region. However, there is a lack of a comprehensive study, in which more chemical species are integrated together in order to get more comprehensive insights of the physical and chemical processes of the air pollutants in region. In addition, the ozone formation on a regional scale needs to be studied. Several studies (Apel et al., 2010; Tie et al., 2009b) suggested that ozone tends to be continuously produced in the city plumes in the downwind region of Mexico City. Zaveri et al. (2003) found, in the 1999 Southern Oxidant Study field campaign in Nashville, Tennessee, that the downwind $\mathrm{O}_{3}$ concentrations in the Nashville plume are more sensitive to $\mathrm{NO}_{\mathrm{x}}$ emissions than anthropogenic VOC emissions. In contrast, the study of Kleinman et al. (2003) suggested that $\mathrm{O}_{3}$ production is VOC-limited in the high$\mathrm{NO}_{\mathrm{x}}$ portions of the Philadelphia urban plume. Thielmann et al. (2002) suggested that in the rural area of Milan, Italy, ozone production per $\mathrm{NO}_{\mathrm{x}}$ consumed is less efficient when the advected air masses originated from Milan. However, there is a lack of intensive studies for the ozone formation at both urban and regional scales of the area surrounding Shanghai, which will be the scientific focus in this study.

The data used in this study are from a field experiment conducted in September 2009. The field experiment called MIRAGE-Shanghai (Megacities Impact on Regional and Global Environment - Shanghai case study) was jointly organized by the Shanghai Meteorological Bureau (SMB) and the Atmospheric Chemistry Division (ACD) of the National Center for Atmospheric Research (NCAR), with several university and research institute participants. The goal of MIRAGE-Shanghai was to characterize the chemical/physical transformations associated with regional air quality. The campaign integrated observations from 7 ground stations, with 3 enhanced ground stations in different parts of the center of city as well as the rural area of the Shanghai region.

Another important goal of the experiment is to compare the observational results with model calculations. The regional chemical/dynamical model used in this study is the state-of-the-art model WRF-Chem. We describe an evaluation of the model performance using measurements from the field experiment. The model is then used to study the characteristics of air pollutants in the urban area and regional exports of air pollution from the urban center to the regional scale to study regional ozone formation in Shanghai and the surrounding area.

The paper is organized as follows: in Sect. 2, we will describe the field experiment as well as the regional chemical/dynamical model (WRF-Chem). In Sect. 3, the simulated chemical species will be compared to the field measurement, so as to evaluate the performance of the model. Section 4 presents model-based estimates of $\mathrm{O}_{3}$ evolution in the city plumes and the regional ozone production in the surrounding area of Shanghai.

\section{Experiment and chemical model}

\subsection{The measurement information}

A comprehensive field experiment (MIRAGE-Shanghai; Megacities Impact on Regional and Global Environment at 
Table 1. List of institutions and instruments deployed at the PD and DT sites.

\begin{tabular}{|c|c|}
\hline PD site & \\
\hline RH & $\begin{array}{l}\text { Shanghai Meteorological Bureau (SMB) } \\
\mathrm{O}_{3}, \mathrm{CO}, \mathrm{NO}, \mathrm{NO}_{2}, \mathrm{SO}_{2}, \\
\mathrm{BC}, \mathrm{PM}_{1}, \mathrm{PM}_{2.5}, \mathrm{PM}_{10}, \\
\text { Meteorological data (MET), including winds, temperature, pressure, } \\
J\left[\mathrm{NO}_{2}\right] \text {, lidar } \\
\text { Atmospheric Chemistry Division (ACD), NCAR } \\
\mathrm{O}_{3}, \mathrm{NO}, \mathrm{NO}_{2}, \mathrm{NO}_{\mathrm{y}} \\
\text { Light } \mathrm{NMHCs} \text { (online) } \\
\text { NHMCs, including OVOCs (online) } \\
\text { Analysis of biogenic VOCs sampled in southern forest } \\
\text { University of Texas A\&M } \\
\mathrm{HNO}_{3}, \mathrm{HONO}\end{array}$ \\
\hline \multicolumn{2}{|l|}{ DT site } \\
\hline RH & $\begin{array}{l}\text { Shanghai Meteorological Bureau (SMB) } \\
\mathrm{O}_{3}, \mathrm{CO}, \mathrm{NO}, \mathrm{NO}_{2}, \\
\mathrm{BC}, \mathrm{PM}_{1}, \mathrm{PM}_{2.5}, \mathrm{PM}_{10}, \\
\text { Meteorological data (MET), including winds, temperature, pressure, } \\
J\left[\mathrm{NO}_{2}\right] \\
\text { Atmospheric Chemistry Division (ACD), NCAR } \\
\text { NHMCs (cartridges) }\end{array}$ \\
\hline
\end{tabular}

Shanghai) was conducted from 1 to 21 September 2009. Participants in the experiment included Shanghai Meteorological Bureau (SMB), National Center for Atmospheric Research (NCAR), Fudan University, Texas A\&M University, Peking University, and the Institute of Earth and Environment (IEE) of Chinese Academy of Science (CAS). In addition to the intensive measurements of the experiment, routine measurements of air pollutants and meteorological parameters in Shanghai were conducted since 2005 at 6 surface sites operated by Shanghai Meteorological Bureau (SMB) and were made available for this study. The routine measurements include $\mathrm{CO}, \mathrm{NO}, \mathrm{NO}_{2}, \mathrm{SO}_{2}, \mathrm{O}_{3}$, black carbon (BC), particulate matter $\left(\mathrm{PM}_{2.5}\right.$ and $\left.\mathrm{PM}_{10}\right)$, and solar radiation. The meteorological parameters include wind speed and direction, air temperature, humidity, and air pressure. In addition to the routine measurements at the 6 stations, 3 super sites were established with additional instruments for measuring air pollutants, including $\mathrm{NO}_{\mathrm{y}}, \mathrm{HONO}, \mathrm{HNO}_{3}$, and a more complete suite of VOC, as well as aerosol composition and size distribution. Moreover, isoprene concentrations were measured in the major forest region located south of Shanghai. The data from 2 super sites, including a site located at the urban center of Pudong (PD) and a remote site located at the east edge of the city along the coast of the East Sea in Dongtan (DT), are analyzed. The center point of Shanghai is at $31.234^{\circ} \mathrm{N} / 121.472^{\circ} \mathrm{E}$. The PD and DT sites are at $31.219^{\circ} \mathrm{N} / 121.550^{\circ} \mathrm{E}$ and $31.469^{\circ} \mathrm{N} / 121.939^{\circ} \mathrm{E}$, respectively. The DT station is located in a wetland area at the coast of Shanghai, which is relatively remote from the city. The distances from the center of Shanghai to PD and DT are $7.1 \mathrm{~km}$ and $54.8 \mathrm{~km}$, respectively. These 2 sites provide useful information for comparing the characterization of air pollutants in an urban area to the situation in a remote area. The detailed information of the measured chemical species is listed in Table 1. The instruments used in this study have been used widely in various field experiments and carefully calibrated. The detailed information regarding these instruments has been described previously (Geng et al., 2007, 2008; Guenther et al., 2006; Zheng et al., 2008; Apel et al., 2010; Molina et al., 2010). Figure 1 shows the measurement sites and the corresponding emission distributions of $\mathrm{CO}, \mathrm{NO}_{\mathrm{x}}$, and VOCs in the region. The detailed locations of the 3 super sites are indicated by large circles (red for PD and DT), and routine sites are indicated by the small red circles.

\subsection{The WRF-Chem model}

The calculations presented in this study are performed using the WRF-Chem model (version 3) (Weather Research and Forecasting with Chemistry). This modeling system includes two components: a dynamical module and a chemical module. WRF, used here as the dynamical module, is a mesoscale numerical weather prediction system designed to serve both for operational forecasting and atmospheric research needs. The effort to develop WRF has been a partnership between the National Center for Atmospheric Research (NCAR), the National Oceanic and Atmospheric Administration (NOAA), the National Center for Environmental Prediction (NCEP), the Forecast Systems Laboratory (FSL), 


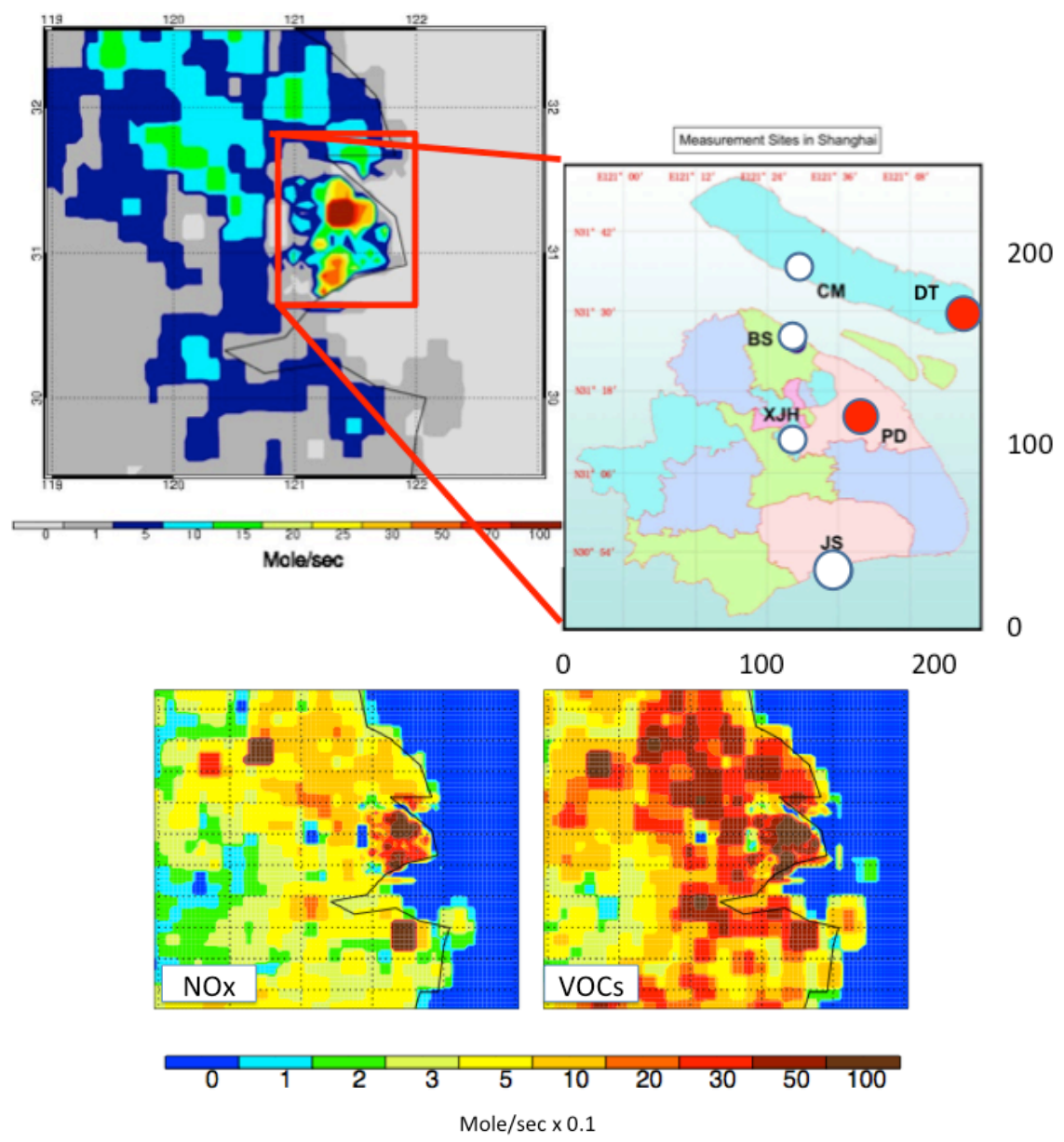

Fig. 1. The measurement sites (top panel) and the corresponding emission distribution of CO (bottom panel) in the Shanghai region. The small red points indicate the routine measurement sites operated by SMB, and the large red points show the 3 super sites during the field experiment.

the Air Force Weather Agency (AFWA), the Naval Research Laboratory, the University of Oklahoma, and the Federal Aviation Administration (FAA). The model equations are solved for fully compressible and nonhydrostatic conditions. A detailed description can be found on the WRF website http://www.wrf-model.org/index.php. In addition to dynamical calculations, a chemical module is coupled online with the WRF model. A detailed description of the chemical component of the model is given by Grell et al. (2005). The ozone formation chemistry is represented in the model by the RADM2 (Regional Acid Deposition Model, version 2) gas-phase chemical mechanism (Chang et al., 1989), which includes 158 reactions among 36 species. The model is used here with some modifications introduced by Tie et al. (2007, 2010). The model was applied to study the regional distributions of $\mathrm{O}_{3}$ concentrations in the Shanghai region. The model result was evaluated by comparing the calculated concentrations with the measured abundances, and the model evaluation suggested that the model is able to predict the large variability of ozone concentrations under different weather con- ditions in the Shanghai region (Tie et al., 2009b). In the current WRF-Chem model, we use the FTUV (fast TUV) mode for the photolysis calculation. The FTUV mode includes the impact of aerosols on ozone chemistry (Tie et al., 2005). Due to high aerosol concentrations in China, the impact of aerosols on the photolysis and ozone chemistry is a very interesting topic. However, this will be a very complex process; a comprehensive analysis should be individually performed. We are planning another separate paper to address this issue.

For this study, the selected horizontal model resolution is $6 \mathrm{~km}$ in a $900 \mathrm{~km} \times 900 \mathrm{~km}$ domain centered around Shanghai. An example of the horizontal distributions of $\mathrm{CO}, \mathrm{NO}_{\mathrm{x}}$, and VOC emissions is shown in Fig. 1. The emission was initially based upon the work of Streets et al. (2003), especially the spatial distributions. However, several previous works have made some improvements for the emission data. For example, Tie et al. (2009a) and Geng et al. (2008, 2009) used the WRF-Chem model to compare extensively with the measurements and to improve the emission inventory. The high resolution $(1 \mathrm{~km} \times 1 \mathrm{~km})$ urban surface data (photographed 

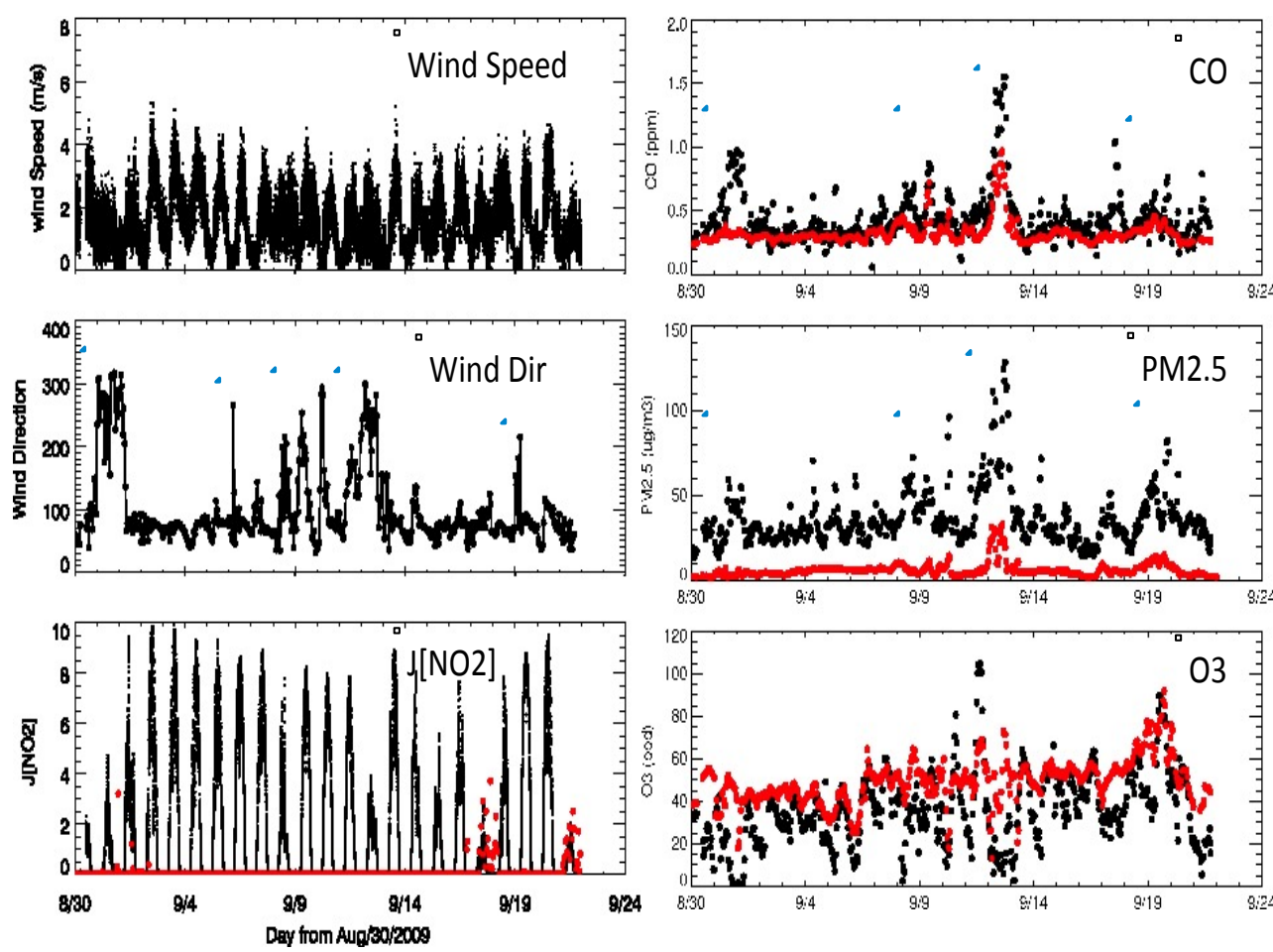

Fig. 2. Measured temporal variations of wind speed $\left(\mathrm{m} \mathrm{s}^{-1}\right)$, wind direction (degree), and photolysis rate $\left(J\left[\mathrm{NO}_{2}\right]\right)(\mathrm{left}$ panels) at $\mathrm{DT}$ site (the red dots in this panel indicate the amount of precipitation). The right panels show the corresponding measured temporal variations $\mathrm{CO}$, $\mathrm{PM}_{2.5}$, and $\mathrm{O}_{3}$ concentrations at PD (black dots) and at DT (red dots).

by airplane) is also applied to improve the horizontal emission distribution. We should note that this high-resolution emission is only limited in the city of Shanghai (from $121^{\circ} \mathrm{E}$ to $122^{\circ} \mathrm{E}$ in longitude, and $30.5^{\circ} \mathrm{N}$ to $31.5^{\circ} \mathrm{N}$ in latitude). As a result, the emission inventory has been improved and can be represented for the current emission inventories in Shanghai. The total emission of $\mathrm{CO}, \mathrm{NO}_{\mathrm{x}}$, and VOCs is listed in Table 1 of Tie et al. (2009a).

In addition to the anthropogenic emissions, the biogenic emissions from vegetation are calculated in this model. The calculation of biogenic emission is particularly important, because this study focuses on the interaction between anthropogenic and biogenic emissions. Biogenic emissions in the model are generated by a biogenic emission module (MEGAN - Model of Emissions of Gases and Aerosols from Nature) developed by Guenther et al. (2006). The biogenic VOC emission distribution can be seen in a separate paper (in this special issue), i.e., Fig. 1 of Geng et al. (2011).

\section{Result and analysis}

\subsection{The background meteorological conditions}

The analysis of wind direction during the period from $30 \mathrm{Au}-$ gust to 23 September 2009 shows that the prevailing winds during the experiment period were east and east-north-east winds (occurring about $62 \%$ ). As indicated in Fig. 1, the prevailing wind transported the less polluted marine air from the Pacific Ocean. However, the wind was from the north of the city for about $10 \%$ of the time. Because there is a heavy industrial complex located in the north of the PD site, the north wind could produce high pollution events at the measurement site. The detailed effects of the wind direction are analyzed in the following sections.

Figure 2 shows the temporal variations of wind speed $\left(\mathrm{m} \mathrm{s}^{-1}\right)$, wind direction (degree), and photolysis rate $\left(J\left[\mathrm{NO}_{2}\right]\right)$, as well as the corresponding $\mathrm{CO}, \mathrm{PM}_{2.5}$, and $\mathrm{O}_{3}$ concentrations. It shows that the wind speed had a strong diurnal variability, with higher wind speeds during the daytime, and lower speeds during the nighttime. The range of wind speeds was from near-zero to $5 \mathrm{~m} \mathrm{~s}^{-1}$, with a mean speed of about $2 \mathrm{~m} \mathrm{~s}^{-1}$, indicating that the winds were not strong during the experiment period. The wind directions showed a high variability. The dominant wind direction was east wind (about 90 degree). However, during several periods, the wind directions switched from east to north winds. There were 3 major north wind periods (defined by the north winds occurring more than 2 days), occurring on 1-2, 8-10, and 1213 September, respectively. There were also 2 minor north wind periods (defined by the north winds occurring on only one day) that happened on 6 and 19 September, respectively. The corresponding $\mathrm{CO}$ and $\mathrm{PM}_{2.5}$ temporal variation showed 
a strong correlation with the wind direction. For example, during the major north wind period of 12-13 September, the $\mathrm{CO}$ and $\mathrm{PM}_{2.5}$ concentrations increased rapidly, reaching to $1.5 \mathrm{ppm}$ and $130 \mu \mathrm{g} \mathrm{m}^{-3}$ at the PD site, compared with the concentrations of $0.4-0.5 \mathrm{ppm}$ and $30-50 \mu \mathrm{g} \mathrm{m}^{-3}$ during the east wind period, suggesting that the wind direction had a significant impact on the air pollutants, especially the primary air pollutants that are directly emitted from the surface. In the following sections, we define the three major north wind periods as the "north wind period", and the east wind period as the "east wind period".

Some important characterizations are also shown in the measurements in Fig. 2. First, during the "north wind period", the high aerosol loadings had an impact on the photolysis rate of $J\left[\mathrm{NO}_{2}\right]$. For instance, the photolysis rate on 13 September was significantly lower than the rate on 14 September. During both days, there was a clear sky condition without precipitation, suggesting that the UV radiation was reduced by heavy aerosol conditions. Second, the differences of $\mathrm{CO}, \mathrm{PM}_{2.5}$ and $\mathrm{O}_{3}$ between the urban (PD) and remote (DT) sites were not the same. For longer lifetime species (CO), the concentrations were not very different between PD and DT during the "clean period". This result suggests that there was a background $\mathrm{CO}$ concentration (about $400 \mathrm{ppbv}$ ), which was regionally transported from surrounding areas. In contrast, for shorter lifetime species $\left(\mathrm{PM}_{2.5}\right)$, the concentrations were very different between PD and DT. The concentrations of $\mathrm{PM}_{2.5}$ were significantly higher in the urban site (PD) than in the remote site (DT), suggesting that the local emissions of $\mathrm{PM}_{2.5}$ dominated impacts on the $\mathrm{PM}_{2.5}$ pollution in the urban areas of Shanghai.

\subsection{Model evaluation}

The model performance for calculating the variability of air pollutants is evaluated at 2 measurement sites (PD and DT). The differences between urban (PD) and rural areas (DT) for the characteristics of air pollutants and ozone chemical formation are analyzed from the results at the 2 sites. Figure 3 shows the measured and calculated concentrations of $\mathrm{CO}, \mathrm{O}_{3}$ and $\mathrm{PM}_{2.5}$ at PD and DT, respectively. At the PD site, the calculated $\mathrm{CO}$ concentrations were generally consistent with the measured results, except that the small-scale variability cannot be simulated due to the relatively coarse resolution $(6 \mathrm{~km})$ of the model. However, at the DT site, the calculated $\mathrm{CO}$ concentrations consistently underestimated the measured values during east wind periods ("clean period"). The underestimation of the $\mathrm{CO}$ concentrations at this remote site during east wind period suggested that the calculated longrange transport of $\mathrm{CO}$ was underestimated. During the north wind periods ("polluted period"), the calculated CO concentrations were elevated, indicating that the CO pollution was transported from polluted sources in Shanghai. Because there were no local CO sources at DT, the regional transport must have an important role in controlling $\mathrm{CO}$ concentration. In
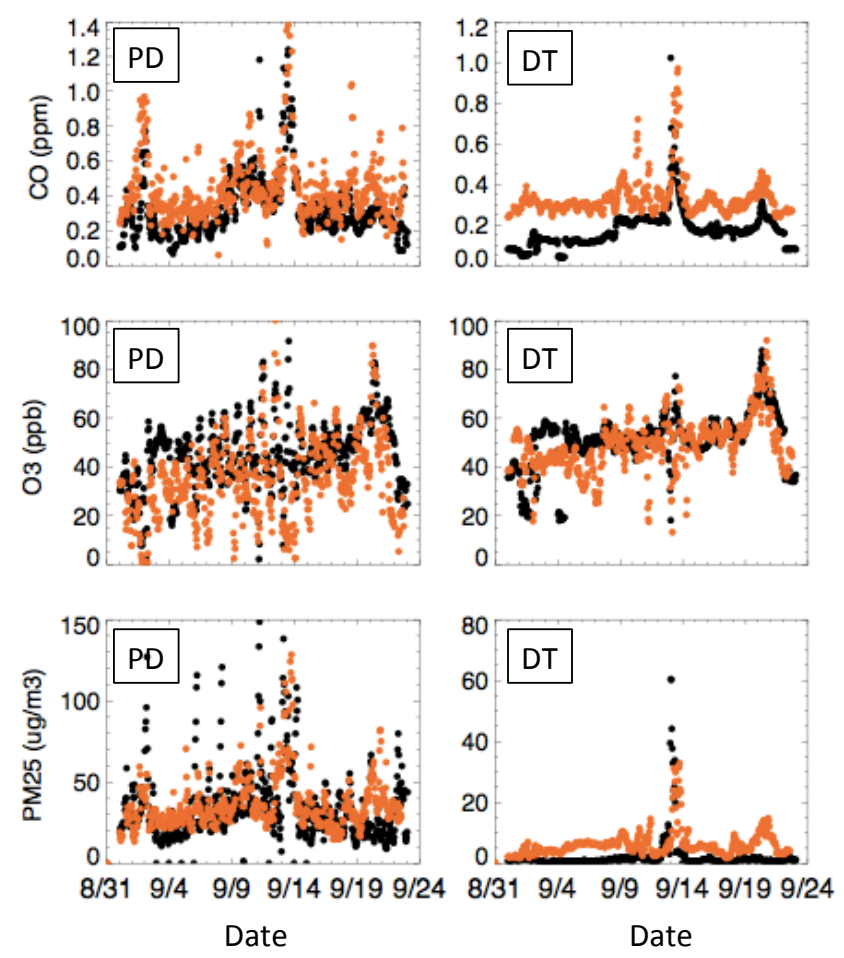

Fig. 3. The measured and calculated $\mathrm{CO}$ and $\mathrm{O}_{3}$ variability at $\mathrm{PD}$ (left panels) and DT sites (right panels). The measured results are represented by the orange dots and calculated results by the black dots, respectively.

the "north wind period", the model calculation of $\mathrm{CO}$ was similar to the measured results, suggesting that the smallscale transport from the urban area to the remote region can be simulated by the model.

The calculated $\mathrm{O}_{3}$ concentrations were very similar to the measured values at both the PD and DT sites. The calculated and measured $\mathrm{O}_{3}$ concentrations showed a larger variability at PD compared with the variability at DT. Unlike the calculated $\mathrm{CO}$ at DT, the calculated $\mathrm{O}_{3}$ concentrations were consistent with the measured value and variability. For example, the $\mathrm{O}_{3}$ peak on 21 September was similar for both the measured and calculated results, indicating that the calculated photochemistry and long-range transport of $\mathrm{O}_{3}$ was reasonable compared with the measured results.

The calculated $\mathrm{PM}_{2.5}$ concentrations were generally in good agreement with the measured concentrations. The calculated temporal variability was larger, which was consistent with the measured variability. For example, during the "polluted period" (12-13 September), both the measured and calculated $\mathrm{PM}_{2.5}$ concentrations rapidly increased. However, there was an indication that the calculated $\mathrm{PM}_{2.5}$ concentrations were underestimated during the "clean period".

Figure 4 shows the measured and calculated temporal variations for the nitrogen family (including $\mathrm{NO}_{\mathrm{x}}=\mathrm{NO}+\mathrm{NO}_{2}$, $\mathrm{HNO}_{3}, \mathrm{HONO}$, and $\mathrm{NO}_{\mathrm{y}}$ (sum of the total nitrogen species)) 

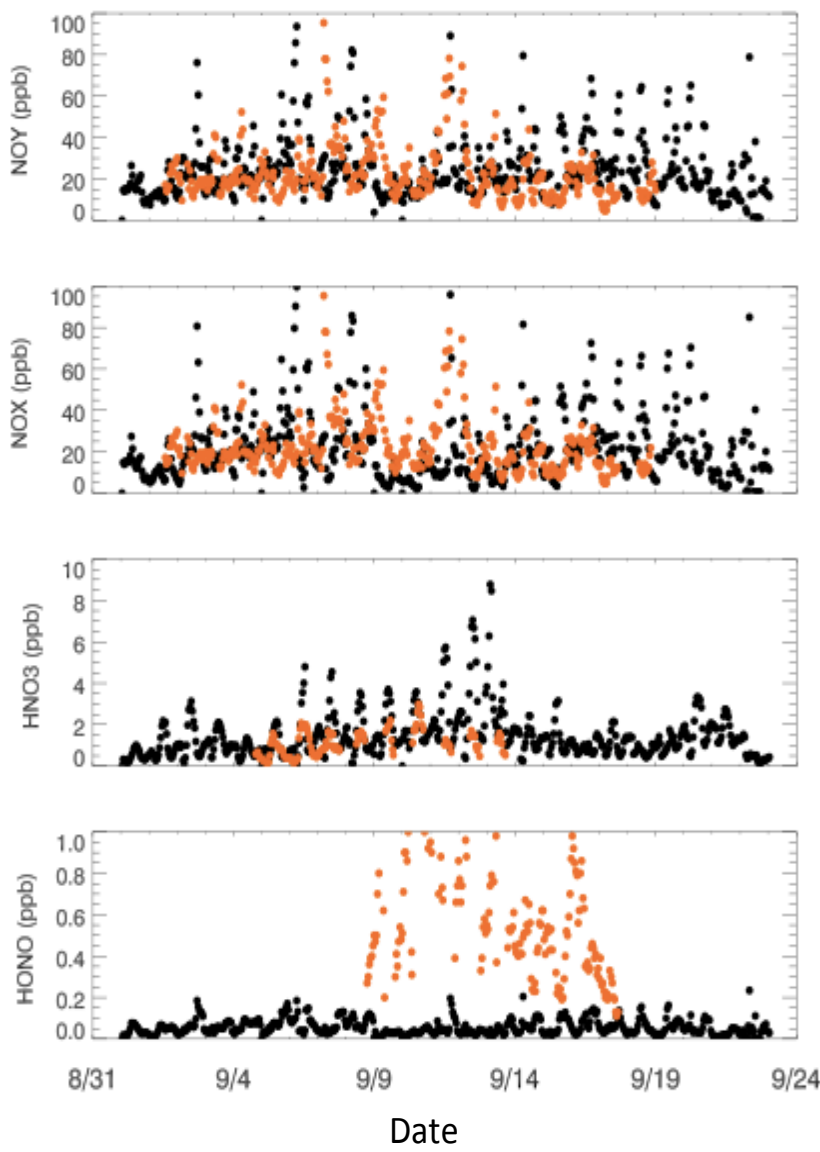

Fig. 4. The measured (orange dots) and calculated (black dots) temporal variability of $\mathrm{NO}_{\mathrm{y}}, \mathrm{NO}_{\mathrm{x}}, \mathrm{HNO}_{3}$, and $\mathrm{HONO}$ concentrations at PD station.

at the urban site (PD). Some of the nitrogen species, such as PAN (peroxyacetyl nitrate) and MPAN (peroxymethacrylic nitrate) were not measured during the experiment. However, we find that the calculated and measured ratios of $\mathrm{NO}_{\mathrm{x}} / \mathrm{NO}_{\mathrm{y}}$ were 0.92 and 0.99 , respectively, indicating that the dominated nitrogen species was $\mathrm{NO}_{\mathrm{x}}$, and the missing nitrogen species had only a small contribution to the total nitrogen family during the experiment. The variability of $\mathrm{NO}_{\mathrm{x}}$ and $\mathrm{NO}_{\mathrm{y}}$ was large, varying from 5 to $80 \mathrm{ppbv}$. Because $\mathrm{NO}_{\mathrm{x}}$ contained more than $90 \%$ of total nitrogen species, the variability of $\mathrm{NO}_{\mathrm{x}}$ was similar to $\mathrm{NO}_{\mathrm{y}}$. The large variability of $\mathrm{NO}_{\mathrm{x}}$ suggested that there were large local impacts on $\mathrm{NO}_{\mathrm{x}}$ concentrations at the PD site. The calculated $\mathrm{HNO}_{3}$ concentrations were consistent with measured values during the "clean period". However, during the "polluted period", the calculated $\mathrm{HNO}_{3}$ concentrations overestimated the measured values. The calculated HONO concentrations were significantly underestimated compared to the measured values, indicating that some important chemical processes for the formation of HONO were not included in the current WRF-Chem model. For example, as suggested by Qin et al. (2009), the effect of
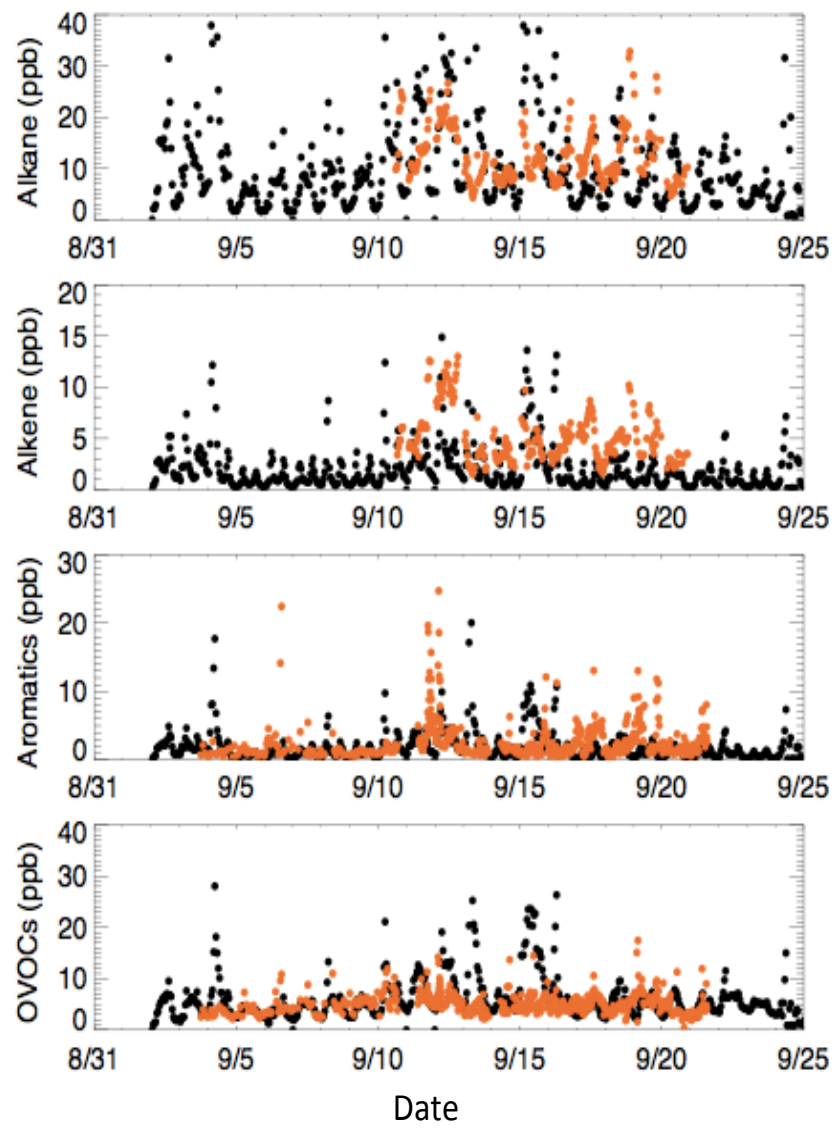

Fig. 5. The measured (orange dots) and calculated (black dots) temporal variability of VOC concentrations as alkanes, alkenes, aromatics, and OVOCs at the PD site.

relative humidity has an important impact on the formation of HONO in southern China.

Figure 5 shows several important volatile organic compounds (VOCs), including alkanes, alkenes, aromatics, and oxygenated VOCs (OVOCs). At the PD site, there are 2 online VOC instruments. One instrument (Apel et al., 2010) is the Trace Organic Gas Analyzer (TOGA), an in situ gas chromatograph/mass spectrometer (GC-MS). The TOGA instrument continuously measured every $2.8 \mathrm{~min} 32$ species including select NMHCs (non-methane hydrocarbons), halogenated compounds, and monofunctional non-acid OVOCs. The detailed species measured by TAGO are listed in Table 1 of Apel et al. (2010). Another instrument is the GCMS/NCAR-ACD for continuously measuring light hydrocarbons (including $\mathrm{C}_{2} \mathrm{H}_{6}, \mathrm{C}_{2} \mathrm{H}_{4}, \mathrm{C}_{3} \mathrm{H}_{8}, \mathrm{C}_{3} \mathrm{H}_{6}, \mathrm{C}_{2} \mathrm{H}_{2}, \mathrm{iC}_{4} \mathrm{H}_{10}$, and $\left.\mathrm{nC}_{4} \mathrm{H}_{10}\right)$ with time resolution of $45 \mathrm{~min}$. The measured values show a high variability for alkanes, with relatively high concentrations. The calculated alkane concentrations were within the range of the measured values. For example, the high episodes of alkane concentrations 12-13 September were measured and simulated. However, the high concentrations predicted by the model for 15-16 September 
Table 2. Comparison of the calculated mean values (variances) at the PD and DT sites with the measured results.

\begin{tabular}{lcrrrrrr}
\hline & \multicolumn{3}{c}{ Measured } & \multicolumn{2}{c}{ Calculated } & \multicolumn{2}{c}{ Meas-Calcu } \\
\hline Species & Sites & \multicolumn{1}{c}{ Mean } & (Vari) & Mean & (Vari) & Diff & Diff (\%) \\
\hline $\mathrm{CO}(\mathrm{ppb})$ & $\mathrm{PD}$ & 439.80 & $(206.30)$ & 479.30 & $(177.96)$ & -39.5 & -5.9 \\
& $\mathrm{DT}$ & 327.07 & $(94.02)$ & 172.73 & $(91.69)$ & 54.3 & 47.1 \\
$\mathrm{O}_{3}(\mathrm{ppb})$ & $\mathrm{PD}$ & 34.96 & $(17.66)$ & 41.23 & $(13.75)$ & -6.2 & -17.9 \\
& $\mathrm{DT}$ & 48.91 & $(10.74)$ & 50.94 & $(11.34)$ & -2.0 & -4.1 \\
$\mathrm{PM}_{2.5}\left(\mu \mathrm{g} \mathrm{m}^{-3}\right)$ & $\mathrm{PD}$ & 36.40 & $(16.70)$ & 33.9 & $(21.80)$ & 2.5 & 6.8 \\
& $\mathrm{DT}$ & 6.04 & $(4.08)$ & & & & \\
$\mathrm{NO}_{\mathrm{x}}(\mathrm{ppb})$ & $\mathrm{PD}$ & 22.51 & $(12.43)$ & 21.20 & $(16.47)$ & 1.3 & 5.8 \\
& $\mathrm{DT}$ & 1.99 & & $(1.46)$ & & & \\
$\mathrm{NO}_{\mathrm{y}}(\mathrm{ppb})$ & $\mathrm{PD}$ & 22.49 & $(13.28)$ & 23.80 & $(14.33)$ & -1.3 & -5.8 \\
$\mathrm{HNO}_{3}(\mathrm{ppb})$ & $\mathrm{PD}$ & 1.08 & $(0.61)$ & 1.42 & $(1.15)$ & -0.3 & -31.4 \\
$\mathrm{HONO}_{(\mathrm{ppb})}$ & $\mathrm{PD}$ & 0.58 & $(0.31)$ & 0.06 & $(0.03)$ & 0.5 & 89.6 \\
Alkane $(\mathrm{ppb})$ & $\mathrm{PD}$ & 12.41 & $(5.36)$ & 10.96 & $(12.24)$ & 1.4 & 11.6 \\
Alkene $(\mathrm{ppb})$ & $\mathrm{PD}$ & 4.27 & $(9.50)$ & 5.16 & $(4.93)$ & -0.8 & -20.8 \\
Aromatic $(\mathrm{ppb})$ & $\mathrm{PD}$ & 2.71 & $(3.10)$ & 1.91 & $(2.58)$ & 0.8 & 29.5 \\
OVOCs $(\mathrm{ppb})$ & $\mathrm{PD}$ & 5.13 & $(2.60)$ & 6.03 & $(4.80)$ & -9.0 & 17.5 \\
VOC_sum $(\mathrm{ppb})$ & $\mathrm{PD}$ & 24.53 & & 24.06 & & 0.4 & 1.8 \\
\hline
\end{tabular}

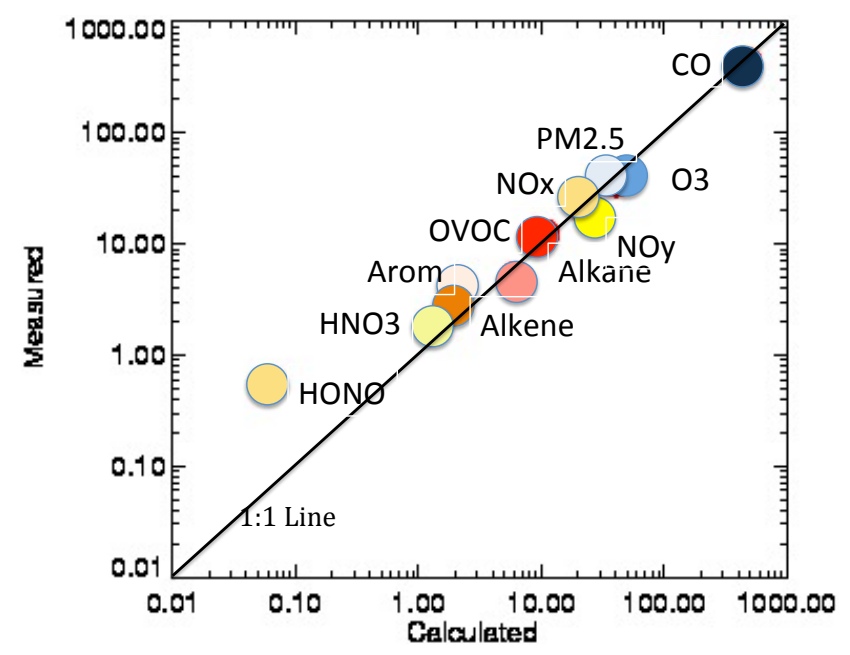

Fig. 6. Comparisons of the mean values of measured (y-coordinate) and calculated (y-coordinate) air pollutants $\left(\mathrm{CO}, \mathrm{O}_{3}, \mathrm{PM}_{2.5}\right.$, etc) at the PD site.

overestimated the observed values. For the alkene concentrations, the high concentrations during the episode of $12-$ 13 September were predicted by the model that was consistent with the measurements. However, the calculation underestimated observed values for other periods. The calculated aromatic concentrations were generally consistent with the measurements, except during some high variability events. The OVOC concentrations had a smaller variability than alkane and alkene concentrations. The calculated result was very similar to the measured values, especially during the "clean periods".
The overall comparison of the mean values and variation between the model calculations and the measurements are shown in Table 2 and Fig. 6. Table 2 shows that the biggest inconsistency between the model calculation and measurement is the HONO concentrations. The calculated HONO concentrations in WRF-Chem (with only gas-phase chemistry of HONO) underestimated the measured values by about $90 \%$, indicating that heterogeneous chemistry might play an important role in Shanghai. The high value of HONO was also measured in the PRD (Pearl River delta) region. As shown by Qin et al. (2009), the HONO concentration measured in PRD had a maximum value of 2 ppbv, which is consistent with the measured high values of HONO in this study. In order to test the underestimation of HONO on the calculated $\mathrm{O}_{3}$ concentration, a sensitivity model study is conducted by multiplying the photolysis rate of HONO by a factor of 10 . The result of the sensitivity study shows that the calculated $\mathrm{O}_{3}$ concentration has not significantly changed by the increase in the photolysis rate of HONO. The maximum change (about 1 ppbv increase in $\mathrm{O}_{3}$ concentration) is near the city area. This sensitivity study suggests that the following study on the ozone formation in the Shanghai region should not be significantly affected by the underestimation of HONO concentrations.

The other important inconsistencies between calculation and measurement include the underestimation of $\mathrm{CO}$ at DT. As mentioned previously, the underestimation at this remote site was mainly due to long-range transport. Other calculations indicate that the modeled mean differences were within $30 \%$ of the measurements. For example, the calculated $\mathrm{O}_{3}$ concentration differences at the PD and DT sites were within 18 and $4 \%$ compared to the measured values. The important precursors of $\mathrm{O}_{3}\left(\mathrm{NO}_{\mathrm{x}}\right.$ and VOCs) were within 6 and $4 \%$, 

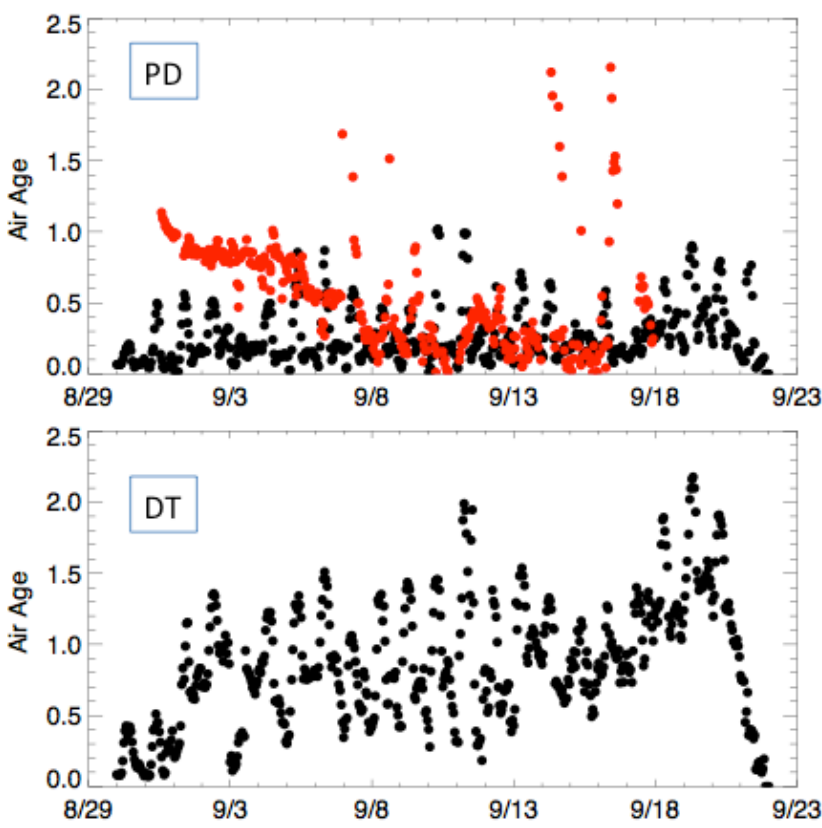

Fig. 7. The measured and calculated chemical age at the PD site (upper panel) and calculated age at the DT site (lower panel) during the experiment. The black and red dots represent the calculated and measured ages at the PD site, respectively.

respectively, at $\mathrm{PD}$. The calculated $\mathrm{PM}_{2.5}$ concentration was within $7 \%$ compared to the measured mean value at the PD site. The variations of the calculated results were generally smaller than the measurements, due to the model horizontal resolution $(6 \mathrm{~km})$. This model evaluation suggests that the model estimates of $\mathrm{PM}_{2.5}$ and $\mathrm{O}_{3}$ and its precursors are generally consistent with measured values, and the WRF-Chem model can be applied to study the processes controlling atmospheric chemistry in the Shanghai region, especially the formation of $\mathrm{O}_{3}$.

\section{Discussions}

\subsection{The chemical ages}

The chemical ages at the PD and DT sites are analyzed in this study. The chemical age of the city plume is defined by Kleiman et al. (2003) and is expressed by

$\mathrm{AG}=-\mathrm{Ln}\left(\mathrm{NO}_{\mathrm{x}} / \mathrm{NO}_{\mathrm{y}}\right)$.

This age analysis was applied to the ozone formation in the Mexico City plume by Tie et al. (2009b). Their study suggests that the age of city plumes was generally young (with AG of $0-1$ ) near the city, and middle-aged (with AG of 1-2) or old-aged (with $\mathrm{AG}>2$ ) in the several hundred kilometers downwind of the city.

Figure 8 shows the measured and calculated air age at the PD site (upper panel) and calculated air age at DT site (lower

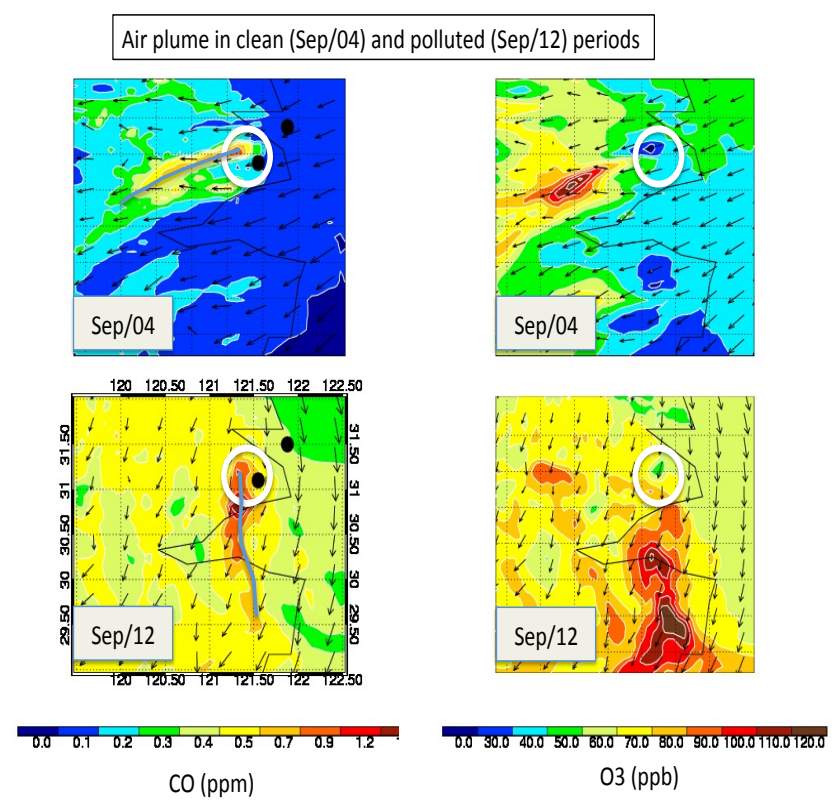

Fig. 8. The calculated horizontal distribution of $\mathrm{CO}$ in different meteorological conditions. The upper panel shows a typical eastern wind condition in September 2004, resulting in a lower CO concentrations in the Shanghai region. The lower panel shows a typical northern wind condition, producing higher $\mathrm{CO}$ concentration in the Shanghai region.

panel) during the experiment. In the urban part of Shanghai (at PD), the measured chemical ages were young, with AG being generally smaller than 1 , except some occasions with AG of 1-2. The calculated AG at PD and DT shows that the values of chemical age at PD range of 0-1 (young age), which is consistent with the measured result. This result suggests that, in the urban site of Shanghai, local emissions play important roles in controlling the concentrations of air pollutants. At the remote site (DT), the calculated values of chemical age were higher than the age at $\mathrm{PD}$, in the range of $0-2$ with frequent values of $1-2$, showing that, at the DT site, regional transport plays an important role in controlling the concentrations of air pollutants.

\subsection{The ozone plumes in the region}

Apel et al. (2010) and Tie et al. (2009b) showed that there was considerable ozone formation in the aged city plumes in the Mexico City region. In this study, the ozone chemical production in the aged city plumes is studied in the Shanghai region. As we mentioned before, the PD site was in the young plume. In order to study the ozone production in the old city plumes in Shanghai, the WRF-Chem model, evaluated in Sect. 3, was applied.

Figure 9 illustrates the city plumes in 2 different cases. The first case (case 1; the upper panels) shows the calculated $\mathrm{CO}$ and $\mathrm{O}_{3}$ plumes in the Shanghai region on 4 September, when the city pollution was defined as "clean period", with 

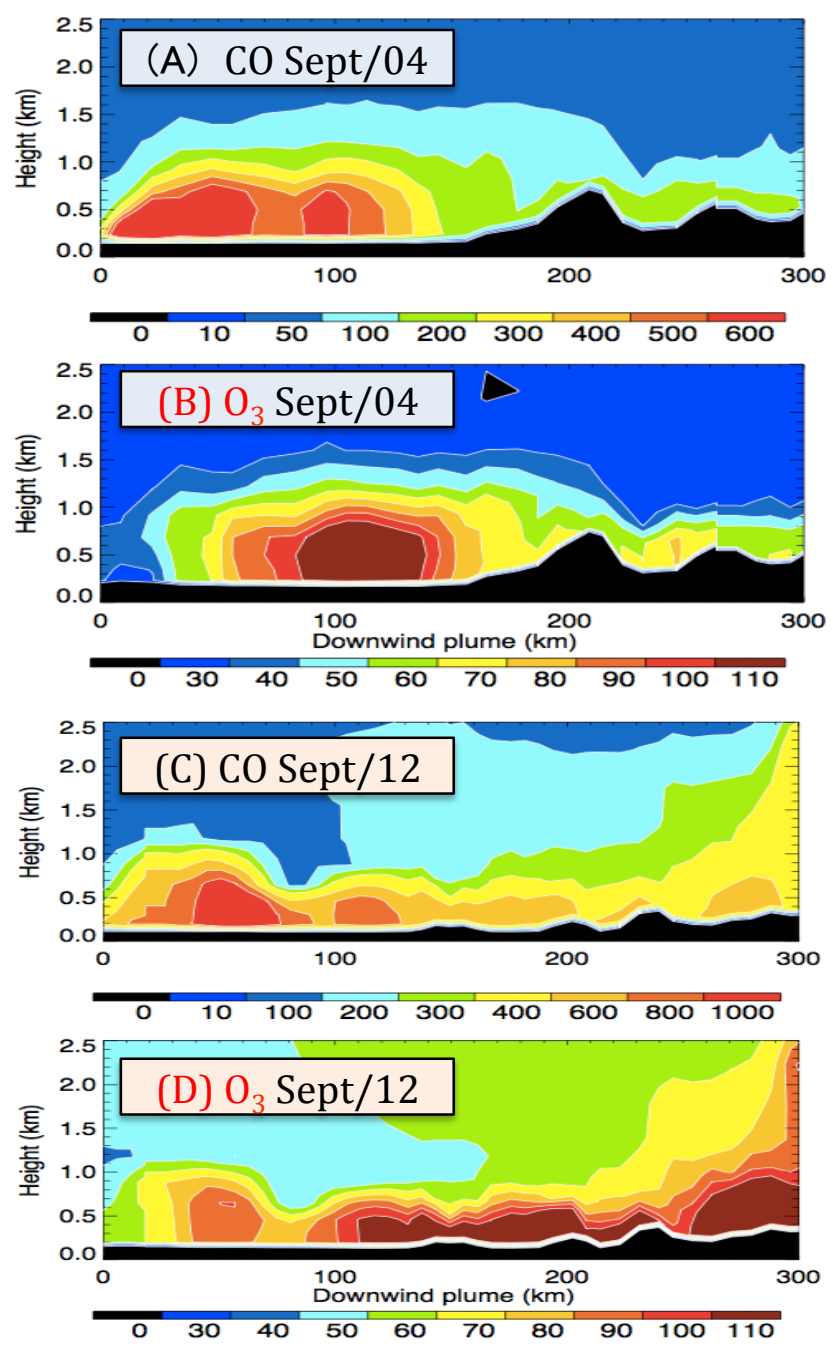

Fig. 9. The calculated cross section (altitude-downwind distances) of the city plumes of $\mathrm{CO}$ and $\mathrm{O}_{3}$ on 4 September (clean period) and 12 September (polluted period), respectively.

a typical east wind condition. The second case (case 2; the lower panels) shows the calculated $\mathrm{CO}$ and $\mathrm{O}_{3}$ plumes in the Shanghai region on 12 September, when the city pollution was defined as "polluted period", with a typical north wind condition. In both cases, the long-lived CO plumes are used to trace the city plumes. As shown in Fig. 10, during case 1 , the $\mathrm{CO}$ concentrations have a maximum in the city, and were transported westerly to the downwind area. In contrast, the $\mathrm{O}_{3}$ concentrations had a minimum in the city, and were enhanced in the downwind areas of Shanghai. During case 2 , the $\mathrm{CO}$ concentrations had a maximum in the city, and were transported southerly to the downwind areas of Shanghai. The same as with case 1 , the $\mathrm{O}_{3}$ concentrations had a minimum in the city, and were enhanced in the downwind areas. The evolution of the $\mathrm{CO}$ and $\mathrm{O}_{3}$ plumes along the downwind areas was clearly shown in Fig. 11. For example, in case 1 , the maximum of $\mathrm{CO}$ occurred at $50 \mathrm{~km}$ within
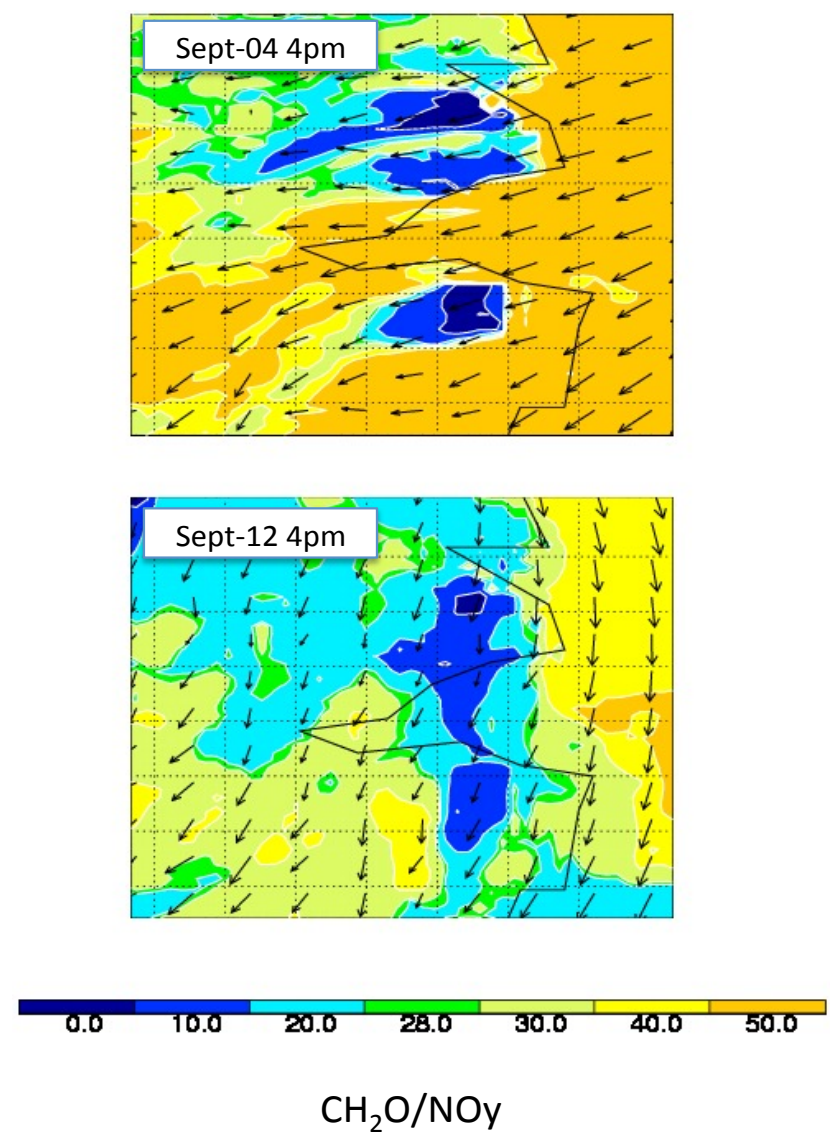

Fig. 10. The calculated ratio of $\mathrm{CH}_{2} \mathrm{O} / \mathrm{NO}_{y}$ on 4 September (clean period) and 12 September (polluted period), respectively. When the ratio is less than 0.28 (as indicated by the blue area), the area is under the VOC-limited condition for ozone formation, while a higher ratio indicates that the area is under the $\mathrm{NO}_{\mathrm{x}}$-limited condition.

the city, and was dispersed at $150 \mathrm{~km}$ from the downwind of the city. However, the $\mathrm{O}_{3}$ concentrations had a minimum within $20 \mathrm{~km}$ of the city, and enhanced at $100-150 \mathrm{~km}$ downwind of the city. In case 2, the maximum of $\mathrm{CO}$ occurred at $80 \mathrm{~km}$ within the city, and dispersed at $200 \mathrm{~km}$ downwind of the city. In contrast, the $\mathrm{O}_{3}$ concentrations had a minimum within $20 \mathrm{~km}$ of the city, and enhanced at 100-300 km downwind of the city. In addition, the enhancement in the ozone was much higher in the downwind areas in case 2 than in case 1 , which will be investigated in the following sections.

\subsection{Ozone formation in the city plumes}

In order to analyze the ozone formation in the city plumes, the sensitivity of $\mathrm{O}_{3}$ photochemical production to its main precursors (VOC and $\mathrm{NO}_{\mathrm{x}}$ ) in the Shanghai region is analyzed. Several previous studies (Geng et al., 2007; Ran et al., 2009; Tie et al., 2009a) suggested that the ozone formation in the city of Shanghai is limited by the concentrations of VOCs (VOC-limited). These studies also suggest that the 

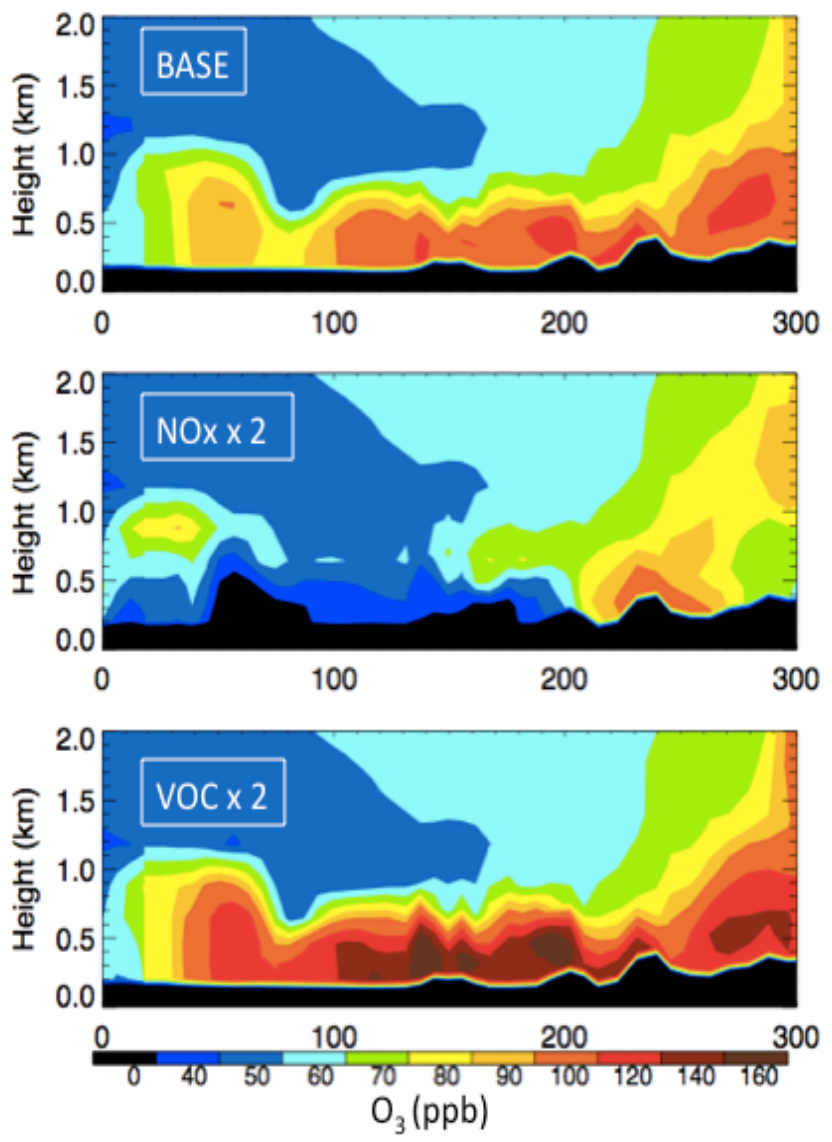

Fig. 11. The calculated cross section (altitude-downwind distances) of the city plumes of $\mathrm{O}_{3}$ on 12 September, due to different emissions, such as the base model run (upper panel), doubled $\mathrm{NO}_{\mathrm{x}}$ emissions (middle panel), and doubled VOC emissions (lower panel).

ozone concentrations were significantly depressed by $\mathrm{NO}_{\mathrm{x}}$ concentrations in the city, indicating that the ozone formation in the urban areas of the city was VOC-limited. This VOC-limited case leads to the ozone minimum in Shanghai (as shown in Fig. 9). In this study, the scientific focus is not only ozone formation in urban Shanghai, but also ozone formation on a regional scale, such as the rural and surrounding areas of Shanghai.

Figure 11 shows the ratios of $\mathrm{CH}_{2} \mathrm{O} / \mathrm{NO}_{\mathrm{y}}$ in the Shanghai region. According to the study by Sillman (1995), this ratio can be used to identify whether the ozone formation is under the VOC-limited or $\mathrm{NO}_{\mathrm{x}}$-limited conditions. According to the study of Sillman (1995), a correlation of $\mathrm{O}_{3}-\mathrm{NO}_{\mathrm{x}}-\mathrm{VOC}$ sensitivity with an indicator of $\mathrm{HCHO} / \mathrm{NO}_{\mathrm{y}}$ is calculated by a photochemical model. The indicator correlation is based on a series calculation with varying rates of anthropogenic and biogenic emissions and meteorology. The results suggest that when the ratio of $\mathrm{CH}_{2} \mathrm{O} / \mathrm{NO}_{\mathrm{y}}$ is smaller than 0.28 , the ozone formation is under the VOC-limited condition, while a ratio of $\mathrm{CH}_{2} \mathrm{O} / \mathrm{NO}_{\mathrm{y}}$ larger than 0.28 indicates ozone formation that is under the $\mathrm{NO}_{\mathrm{x}}$-limited condition. We have used an- other method suggested by Kleinman et al. (2003), which used the calculation of radical budget to determine the ozone sensitivity to VOC and $\mathrm{NO}_{\mathrm{x}}$. The comparison of the two methods is very similar, indicating that the Sillman's method is very robust and suitable for the ozone sensitivity study.

For example, for case 1, in the western part of Shanghai, there was a large area with a ratio smaller than 0.28 , indicating that the ozone formation was in the VOC-limited region. Along the downwind city plume, the initial ozone formation was strongly under the VOC-limited region (in the urban area of Shanghai). As a result, the ozone concentrations were depressed by high $\mathrm{NO}_{\mathrm{x}}$ concentrations near the city, leading to a minimum of ozone in the urban area.

The lower panel of Fig. 11 shows that, during case 2, the ozone formation was under the VOC-limited regime along the city plume pathway. This result suggests that ozone can be continuously produced along the pathway when additional VOCs are emitted in the city plume. According to the study by Geng et al. (2011), there is a large area of forest south of Shanghai. The biogenic emission of isoprene from the forest leads to very high isoprene concentrations in this region. According to their study, isoprene concentrations of 1$6 \mathrm{ppbv}$ were measured in the forest area. These high isoprene concentrations produced important ozone production on a regional scale.

Model sensitivity runs were performed to test the hypothesis that ozone production was continuously increased by enhancement of VOCs along the city plume in case 2, including (a) Run 0 (base run), (b) Run 1 (the emission of $\mathrm{NO}_{\mathrm{x}}$ is doubled), and (c) Run 2 (the emission of VOCs is doubled). Figure 12 shows the cross sections (latitude height) along the city plumes on 12 September (as indicated in Fig. 9) of the 3 model studies. The results show that in Run 0 there was an ozone minimum in the city, and ozone concentrations were enhanced downwind of the city. The result of Run 1 shows that the ozone concentrations were significantly reduced by the higher $\mathrm{NO}_{\mathrm{x}}$ concentrations compared to Run 0 , indicating that, in the VOC-limited regions (in the city and the surrounding areas of Shanghai), high $\mathrm{NO}_{\mathrm{x}}$ concentrations play an important role by depressing ozone concentrations. In contrast, by increasing VOC emissions, the ozone concentrations were significantly enhanced in the city plume. For example, in the $150 \mathrm{~km}$ downwind, the ozone concentrations were 100, 40, and 140 ppbv, for Run 0, Run 1, and Run 2, respectively. This result shows that ozone concentrations were increased by the emissions of VOCs in the city plume, which was under the VOC-limited condition.

\subsection{Impact of $\mathrm{NO}_{\mathrm{x}} / \mathrm{VOCs}$ emission ratio on ozone formation}

The above sensitivity study suggests that the change from VOC-limited to $\mathrm{NO}_{\mathrm{x}}$-limited conditions in Shanghai is strongly related to the ratio of $\mathrm{NO}_{\mathrm{x}}$ and VOC concentrations in the region, suggesting that changes in the emission ratio 

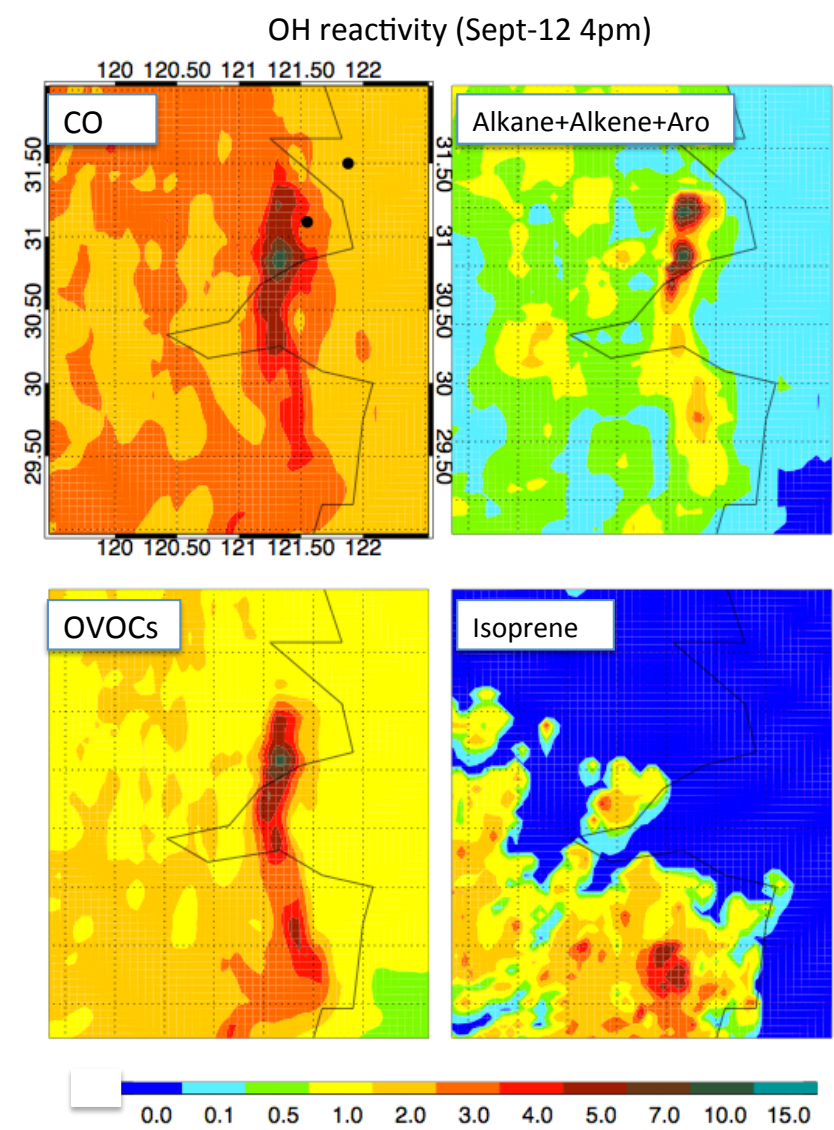

Fig. 12. The calculated $\mathrm{OH}$ reactivity for different species in the Shanghai region, including $\mathrm{CO}$, alkane + alkene + aromatics, OVOCs, and isoprene.

of $\mathrm{NO}_{\mathrm{x}}$ / VOCs can significantly affect the ozone formation on a regional scale. Thus, it is important to find a threshold value of emission ratio $\left(\mathrm{NO}_{\mathrm{x}} / \mathrm{VOC}\right)$ in the Shanghai region, under which the VOC-limited condition is switched to a $\mathrm{NO}_{\mathrm{x}}$-limited condition. According to the studies by Apel et al. (2010), the concentration ratio of $\mathrm{NO}_{\mathrm{x}} / \mathrm{VOC}$ in Mexico City in 2006 was about 0.36 , with an emission ratio of 0.1 (Tie et al., 2010). In contrast, the $\mathrm{NO}_{\mathrm{x}} /$ VOCs ratio in Shanghai was about 0.9 , with an emission ratio of 0.4 in this study, which was much higher than Mexico City. In Mexico City, the major fuel used for industrial and human activities is oil/gas, while in Shanghai the major fuel is coal. The difference in the major fuel usages in the two megacities causes a very different $\mathrm{NO}_{\mathrm{x}} / \mathrm{VOCs}$ emission ratio. Four model runs with the different emission ratio of $\mathrm{NO}_{\mathrm{x}} / \mathrm{VOC}(0.1,0.2,0.4$, and 0.8 ) are conducted in the study. To change the emission ratio, the rate of $\mathrm{NO}_{\mathrm{x}}$ emission is fixed, and the emission ratio of $\mathrm{NO}_{\mathrm{x}} / \mathrm{VOC}$ is increased or decreased by changes of the rate of VOC emission. For example, the default emission ratio is 0.4 . The emission ratios of $0.8,0.2$, and 0.1 changed the VOC emission by decreasing VOC emission by a factor of 2 , and increasing by a factor of 2 , and 4 , respectively.
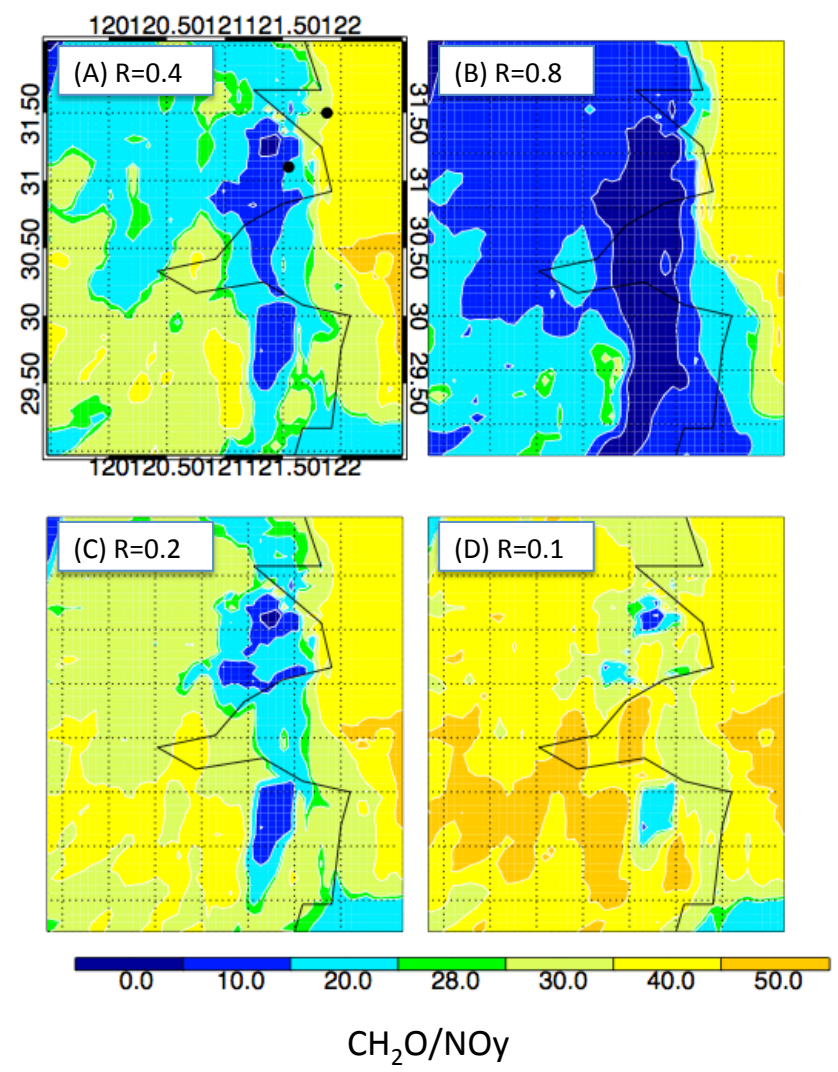

Fig. 13. The calculated ratio of $\mathrm{CH}_{2} \mathrm{O} / \mathrm{NO}_{y}$ on 12 September in the Shanghai region, with different emission ratios of $\mathrm{NO}_{\mathrm{x}} /$ VOCs in the model. The 4 panels represent different emission ratios, such as (A) with the ratio of $0.4,(\mathbf{B})$ with the ratio of $0.8,(\mathbf{C})$ with the ratio of 0.2 , and (D) with the ratio of 0.1 .

The changes in VOC emission are only limited to the anthropogenic emission in the whole model domain. Under the lower emission ratio (e.g., in Mexico City), the ozone formation was VOC-limited only in the center of the city, while in the rural and surrounding areas of Mexico City, the ozone formation was under the $\mathrm{NO}_{\mathrm{x}}$-limited condition. However, in the Shanghai region, because the ratio of $\mathrm{NO}_{\mathrm{x}} / \mathrm{VOCs}$ was very high, it resulted in a very strong VOC-limited condition on a regional scale. As a result, the ozone concentration was continuously increased in the city plumes. According to the study by Tie et al. (2009b) and Geng et al. (2011), the ozone enhancement downwind of the city was mainly attributed to 3 factors: including (a) the oxidation of OVOCs in the plumes, (b) the oxidation of $\mathrm{CO}$ in the plumes, and (c) the biogenic emission of isoprene. These important factors for affecting the ozone formation in the Shanghai region are shown in Fig. 13. The figure shows that the $\mathrm{OH}$ reactivity for $\mathrm{CO}$ had high values in a wide region surrounding the city, especially in the city plume. The $\mathrm{OH}$ reactivity is defined by several previous studies. For example, the R-4 of Apel et al. (2010), and the unit of the $\mathrm{OH}$ reactivity, is $1 \mathrm{~s}^{-1}$. The $\mathrm{OH}$ reactivity of OVOCs had the most important impact on the ozone 
formation in the city plume downwind of the city. This result is consistent with the study by Tie et al. (2010) for the Mexico City case. The $\mathrm{OH}$ reactivity due to the biogenic emission of VOCs (isoprene) had an important effect on ozone formation in the major forest located south of Shanghai, which is consistent with the result of Geng et al. (2011). The above study suggests that understanding the regional ozone formation (either under VOC- or $\mathrm{NO}_{\mathrm{x}}$-limited condition) has very important implications for ozone pollution control not only in the urban area of large cities, but also on a regional scale for the areas surrounding large cities.

In order to quantify the effect of the emission ratio of $\mathrm{NO}_{\mathrm{x}} /$ VOCs on the ozone formation condition on a regional scale, 4 different model runs are performed in this study, including (a) the emission ratio of 0.4 (Run 1), (b) the emission ratio of 0.8 (Run 2), (c) the emission ratio of 0.2 (Run 3), and (d) the emission ratio of 0.1 (Run 4). The result with these 4 model runs is shown in Fig. 14. The figure shows that with the ratio of 0.4 (base run in the model), the city of Shanghai was under a very strong VOC-limited condition. In addition the urban area of the city, a large regional area, especially in the downwind city plume, the ozone formation was also under the VOC-limited condition. With the enhancement of $\mathrm{NO}_{\mathrm{x}}$ emissions in the model (Run 2 with the ratio of 0.8), most regions in the areas surrounding Shanghai, except the ocean area, were under the VOC-limited condition, under which the enhancement of $\mathrm{NO}_{\mathrm{x}}$ strongly depressed the ozone formation in the region. In contrast, by reducing $\mathrm{NO}_{\mathrm{x}}$ emissions or increasing VOC emission (Run 3 with the ratio of 0.2 ), the VOC-limited areas were significantly reduced, and the $\mathrm{NO}_{\mathrm{x}}$-limited condition dominated the region. By further reducing $\mathrm{NO}_{\mathrm{x}}$ emissions or increasing VOC emission (Run 4 with the ratio of 0.1 ), the VOC-limited condition was limited to the center of large cities, and the ozone formation was strongly controlled by the $\mathrm{NO}_{\mathrm{x}}$-limited condition in the region. The ozone formation was enhanced by the increase of $\mathrm{NO}_{\mathrm{x}}$ emission in most regions including in the city plumes. This result suggests that the emission ratio of $\mathrm{NO}_{\mathrm{x}} / \mathrm{VOC}$ is very sensitive to whether the region is under VOC- or $\mathrm{NO}_{\mathrm{x}}-$ limited conditions, with a threshold emission ratio between 0.1 and 0.2 on a regional scale around the Shanghai region. When the ratio is greater than 0.8 , the ozone formation is not sensitive to the emission ratio. Under this high ratio condition, the entire region is under strong VOC-limited conditions for the formation of ozone.

\section{Summary}

The highlights of the results of this study of the Shanghai region are as follows:

1. The air pollution had very strong variability due to the influences of meteorological conditions, especially the wind direction. The air pollution was low with the east wind and much higher with the north wind. We note that this effect is only limited in the Shanghai region.

2. The model is able to simulate most of the measured chemical species, including $\mathrm{CO}, \mathrm{O}_{3}, \mathrm{PM}_{2.5}$, the nitrogen family, and most VOC species (alkanes, alkenes, aromatics, and OVOCs), with the differences between model simulated and measured values being smaller than $30 \%$. However, some discrepancies are also noticeable. For example, the calculated HONO significantly underestimated the measured values (90\%), with only gas-phase HONO chemistry in the model.

3. During the experiment period, the ozone photochemical formation was strongly VOC-limited. The VOC-limited condition occurred not only in the urban area, but also in a large regional area surrounding Shanghai. In addition, the regional distribution of VOC-limited conditions changes with different meteorological conditions. The VOC-limited area was larger for north wind condition (polluted period) than for east wind condition (clean period).

4. The ozone formation was enhanced in the city plumes in the downwind region because the city plumes were under VOC-limited conditions, resulting in an enhanced ozone formation in a large regional area. This study suggests that ozone was continuously produced in the city plumes and could be mainly attributed to the oxidation of OVOCs in the plumes, the oxidation of $\mathrm{CO}$ in the plumes, and the biogenic emission of isoprene.

5. The threshold value of the emission ratio $\left(\mathrm{NO}_{\mathrm{x}} / \mathrm{VOC}\right)$, under which the ozone formation is switched from VOC-limited to $\mathrm{NO}_{\mathrm{x}}$-limited conditions, is studied in the Shanghai region. It shows that, with the ratio of 0.4 (base run in the model), the city of Shanghai and the downwind city plume were under a very strong VOClimited condition. With the enhancement of $\mathrm{NO}_{\mathrm{x}}$ emissions in the model (Run 2 with the ratio of 0.8), most regions in the areas surrounding Shanghai were under the VOC-limited condition. By reducing $\mathrm{NO}_{\mathrm{x}}$ emissions or increasing VOC emission (Run 3 with the ratio of 0.2 ), the $\mathrm{NO}_{\mathrm{x}}$-limited condition dominated in the region. By further reducing $\mathrm{NO}_{\mathrm{x}}$ emissions or increasing VOC emission (Run 4 with the ratio of 0.1 ), the ozone formation was strongly controlled by the $\mathrm{NO}_{\mathrm{x}}-$ limited condition in the region. This result suggests that the emission ratio of the threshold value for switching from the VOC-limited to $\mathrm{NO}_{\mathrm{x}}$-limited conditions ranges from 0.1 to 0.2 in the Shanghai region. 
Acknowledgements. This research is partially supported by National Natural Science Foundation of China (NSFC) under Grant Nos. 41275168 and 41175007 and by the Science Foundation of Chinese Meteorological Administration (CMA) under Grant No. 20126011. The National Center for Atmospheric Research is sponsored by the National Science Foundation.

Edited by: T. Wang

\section{References}

Apel, E. C., Emmons, L. K., Karl, T., Flocke, F., Hills, A. J., Madronich, S., Lee-Taylor, J., Fried, A., Weibring, P., Walega, J., Richter, D., Tie, X., Mauldin, L., Campos, T., Weinheimer, A., Knapp, D., Sive, B., Kleinman, L., Springston, S., Zaveri, R., Ortega, J., Voss, P., Blake, D., Baker, A., Warneke, C., Welsh-Bon, D., de Gouw, J., Zheng, J., Zhang, R., Rudolph, J., Junkermann, W., and Riemer, D. D.: Chemical evolution of volatile organic compounds in the outflow of the Mexico City Metropolitan area, Atmos. Chem. Phys., 10, 2353-2375, doi:10.5194/acp-10-23532010, 2010.

Cai, C. J., Geng, F. H., Tie, X., Yu, Q., and An, J. L.: Characteristics and source apportionment of VOCs measured in Shanghai, China, Atmos. Environ., 44, 5005-5014, doi:10.1016/j.atmosenv.2008.05.045, 2010.

Chang, J. S., Binkowski, F. S., Seaman, N. L., McHenry, J. N., Samson, P. J., Stockwell, W. R., Walcek, C. J., Madronich, S., Middleton, P. B., Pleim, J. E., and Lansford, H. H.: The regional acid deposition model and engineering model, State-ofScience/Technology, Report 4, National Acid Precipitation Assessment Program, Washington DC, USA, 1989.

Geng, F. H., Zhao, C. S., Tang, X., Lu, G. L., and Tie, X.: Analysis of ozone and VOCs measured in Shanghai: A case study, Atmos. Environ., 41, 989-1001, 2007.

Geng, F. H., Tie, X., Xu, J., Zhou, G., Peng, L., Gao, W., Tang, X., and Zhao, C.: Characterization of $\mathrm{O}_{3}, \mathrm{NO}_{\mathrm{x}}$ and VOCs measured in Shanghai, China, Atmos. Environ., 42, 6873-6883, 2008.

Geng, F. H., Qiang, Z., Tie, X., Huang, M., Ma, X., Deng, Z., Quan, J., and Zhao, C.: Aircraft measurements of $\mathrm{O}_{3}, \mathrm{NO}_{\mathrm{x}}, \mathrm{CO}$, VOCs, and $\mathrm{SO}_{2}$ in the Yangtze River Delta region, Atmos. Environ., 43, 584-593, 2009.

Geng, F., Tie, X., Guenther, A., Li, G., Cao, J., and Harley, P.: Effect of isoprene emissions from major forests on ozone formation in the city of Shanghai, China, Atmos. Chem. Phys., 11, 1044910459, doi:10.5194/acp-11-10449-2011, 2011.

Grell, G. A., Peckham, S. E., Schmitz, R., McKeen, S. A., Wilczak, J., and Eder, B.: Fully coupled "online" chemistry within the WRF model, Atmos. Environ. 39, 6957-6975, 2005.

Guenther, A., Karl, T., Harley, P., Wiedinmyer, C., Palmer, P. I., and Geron, C.: Estimates of global terrestrial isoprene emissions using MEGAN (Model of Emissions of Gases and Aerosols from Nature), Atmos. Chem. Phys., 6, 3181-3210, doi:10.5194/acp-63181-2006, 2006.

Jiang, D., Zhang, Y., Hu, X., Zeng, Y., Tan, J., and Shao, D.: Progress in developing an ANN model for air pollution index forecast, Atmos. Environ., 38, 7055-7064, 2004.

Kleinman L. I., Daum, P. H., Lee, Y.-N., Nunnermacker, L. J., Springston, S. R., Weinstein-Lloyd, J., Hyde, P., Doskey, P., Rudolph, J., Fast, J., and Berkowitz, C.: Photochemical age de- terminations in the Phoenix metropolitan area, J. Geophys. Res., 108, 4096, doi:10.1029/2002JD002621, 2003.

Molina, L. T., Madronich, S., Gaffney, J. S., Apel, E., de Foy, B., Fast, J., Ferrare, R., Herndon, S., Jimenez, J. L., Lamb, B., Osornio-Vargas, A. R., Russell, P., Schauer, J. J., Stevens, P. S., Volkamer, R., and Zavala, M.: An overview of the MILAGRO 2006 Campaign: Mexico City emissions and their transport and transformation, Atmos. Chem. Phys., 10, 8697-8760, doi:10.5194/acp-10-8697-2010, 2010.

Qin, M., Xie, P., Su, H., Gu, J., Peng, F., Li, S., Zeng, L., Liu, J., Liu, W., and Zhang, Y.: An observational study of the HONO$\mathrm{NO}_{2}$ coupling at an urban site in Guangzhou City, South China, 43, 5731-5742, doi:10.1016/j.atmosenv., 2009.

Ran, L., Zhao, C. S., Geng, F. H., Tie, X., Tang, X., Peng, L., Zhou, G. Q., Yu, Q., Xu, J. M., and Guenther, A.: Ozone photochemical production in urban Shanghai, China: Analysis based on ground level observations, J. Geophys. Res., 114, D15301, doi:10.1029/2008JD010752, 2009.

Shanghai Municipal Statistics Bureau (SMSB), Shanghai Statistical Yearbook, China Statistical Press (in Chinese), 20-25, 2008.

Sillman, S.: The use of $\mathrm{NO}_{y}, \mathrm{H}_{2} \mathrm{O}_{2}$, and $\mathrm{HNO}_{3}$ as indicators for ozone- $\mathrm{NO}_{\mathrm{x}}$-hydrocarbon sensitivity in urban locations, J. Geophys. Res., 100, 14175-14188, 1995.

Streets, D. G., Bond, T. C., Carmichael, G. R., Fernandes, S. D., Fu, Q., He, D., Klimont, Z., Nelson, S. M., Tsai, N. Y., Wang, M. Q., Woo, J. H., and Yarber, K. F.: An inventory of gaseous and primary aerosol emissions in Asia in the year 2000, J. Geophys. Res., 108, 8809, doi:10.1029/2002JD003093, 2003.

Tang, W. Y., Zhao, C. S., Geng, F. H., and Tie, X.: Study of ozone "weekend effect" in Shanghai, Sci. China, 51, 1354-1360, 2008.

Thielmann, A., Prévôt, A. S. H., and Staehelin, J.: Sensitivity of ozone production derived from field measurements in the Italian Po basin, J. Geophys. Res., 107, 8194, doi:10.1029/2000JD000119, 2002.

Tie, X., Madronich, S., Walters, S., Edwards, D. P., Ginoux, P., Mahowald, N., Zhang, R. Y., Lou, C., and Brasseur, G.: Assessment of the global impact of aerosols on tropospheric oxidants, J. Geophys. Res., 110, D03204, doi:10.1029/2004JD005359, 2005.

Tie, X., Madronich, S., Li, G. H., Ying, Z. M., Zhang, R., Garcia, A., Lee-Taylor, J., and Liu, Y.: Characterizations of chemical oxidants in Mexico City: A regional chemical/dynamical model (WRF-Chem) study, Atmos. Environ., 41, 1989-2008, 2007.

Tie, X., Geng, F. H., Peng, L., Gao, W., and Zhao, C. S.: Measurement and modeling of $\mathrm{O}_{3}$ variability in Shanghai, China; Application of the WRF-Chem model, Atmos. Environ., 43, 42894302, 2009a.

Tie, X., Madronich, S., Li, G., Ying, Z., Weinheimer, A., Apel, E., and Campos, T.: Simulation of Mexico City plumes during the MIRAGE-Mex field campaign using the WRF-Chem model, Atmos. Chem. Phys., 9, 4621-4638, doi:10.5194/acp-9-4621-2009, $2009 b$.

Tie, X., Brasseur, G., and Ying, Z.: Impact of model resolution on chemical ozone formation in Mexico City: application of the WRF-Chem model, Atmos. Chem. Phys., 10, 8983-8995, doi:10.5194/acp-10-8983-2010, 2010.

Yang, F., He, K., Ye, B., Chen, X., Cha, L., Cadle, S. H., Chan, T., and Mulawa, P. A.: One-year record of organic and elemental carbon in fine particles in downtown Beijing and Shanghai, Atmos. Chem. Phys., 5, 1449-1457, doi:10.5194/acp-5-1449-2005, 
2005.

Zaveri R. A., C. M. Berkowitz, L. I. Kleinman, S. R. Springston, P. V. Doskey, W. A. Lonneman, C. W. Spicer, Ozone production efficiency and $\mathrm{NO}_{\mathrm{x}}$ depletion in an urban plume: Interpretation of field observations and implications for evaluating $\mathrm{O}_{3}-\mathrm{NO}_{\mathrm{x}}-\mathrm{VOC}$ sensitivity, J. Geophys. Res., 108, 4436, doi:10.1029/2002JD003144, 2003.

Zhao, C., Peng, L., Sun, A., Qin, Y., Liu, H. L., Li, W. L., and Zhou, X. J.: Numerical modeling of tropospheric ozone over Yangtze Delta region, Acta Sci. Circumst., 24, 525-533, 2004.
Zheng, J., Zhang, R., Fortner, E. C., Volkamer, R. M., Molina, L., Aiken, A. C., Jimenez, J. L., Gaeggeler, K., Dommen, J., Dusanter, S., Stevens, P. S., and Tie, X.: Measurements of $\mathrm{HNO}_{3}$ and $\mathrm{N}_{2} \mathrm{O}_{5}$ using ion drift-chemical ionization mass spectrometry during the MILAGRO/MCMA-2006 campaign, Atmos. Chem. Phys., 8, 6823-6838, doi:10.5194/acp-8-6823-2008, 2008. 